\title{
Aneuploid Cells Are Differentially Susceptible to Caspase- Mediated Death during Embryonic Cerebral Cortical Development
}

\author{
Suzanne E. Peterson, ${ }^{1 \star}$ Amy H. Yang, ${ }^{1 \star}$ Diane M. Bushman, ${ }^{1,2 \star}$ Jurjen W. Westra, ${ }^{1,2}$ Yun C. Yung, ${ }^{1,2}$ Serena Barral, ${ }^{1}$ \\ Tetsuji Mutoh, ${ }^{1}$ Stevens K. Rehen, ${ }^{1}$ and Jerold Chun ${ }^{1}$ \\ ${ }^{1}$ Department of Molecular Biology, Dorris Neuroscience Center, The Scripps Research Institute, La Jolla, California 92037 and ${ }^{2}$ Biomedical Sciences \\ Graduate Program, School of Medicine, University of California San Diego, La Jolla, California 92093
}

\begin{abstract}
Neural progenitor cells, neurons, and glia of the normal vertebrate brain are diversely aneuploid, forming mosaics of intermixed aneuploid and euploid cells. The functional significance of neural mosaic aneuploidy is not known; however, the generation of aneuploidy during embryonic neurogenesis, coincident with caspase-dependent programmed cell death (PCD), suggests that a cell's karyotype could influence its survival within the CNS. To address this hypothesis, PCD in the mouse embryonic cerebral cortex was attenuated by global pharmacological inhibition of caspases or genetic removal of caspase- 3 or caspase-9. The chromosomal repertoire of individual brain cells was then assessed by chromosome counting, spectral karyotyping, fluorescence in situ hybridization, and DNA content flow cytometry. Reducing PCD resulted in markedly enhanced mosaicism that was comprised of increased numbers of cells with the following: (1) numerical aneuploidy (chromosome losses or gains); (2) extreme forms of numerical aneuploidy ( $>5$ chromosomes lost or gained); and (3) rare karyotypes, including those with coincident chromosome loss and gain, or absence of both members of a chromosome pair (nullisomy). Interestingly, mildly aneuploid ( $<5$ chromosomes lost or gained) populations remained comparatively unchanged. These data demonstrate functional non-equivalence of distinguishable aneuploidies on neural cell survival, providing evidence that somatically generated, cell-autonomous genomic alterations have consequences for neural development and possibly other brain functions.
\end{abstract}

\section{Introduction}

A surprising feature of the vertebrate CNS is mosaic aneuploidy, wherein numerous forms of aneuploidy are intermixed among euploid cells (Rehen et al., 2001; Yang et al., 2003; Rajendran et al., 2007). Aneuploidy is the gain and/or loss of chromosomes, deviating from haploid multiples; in mosaic aneuploidy, no single chromosome is uniformly affected. CNS aneuploidy arises during embryonic neurogenesis through mechanisms involving chromosome segregation defects in neural progenitor cells (NPCs) (Yang et al., 2003). Aneuploid NPCs account for 33\% of the total NPC pool at embryonic day 13 (E13) (Rehen et al., 2001), and the gene expression profiles of mosaically aneuploid

\footnotetext{
Received July 31, 2012; revised Sept. 7, 2012; accepted Sept. 16, 2012.

Author contributions: S.E.P., A.H.Y., S.K.R., and J.C. designed research; S.E.P., A.H.Y., J.W.W., Y.C.Y., S.B., T.M., and S.K.R. performed research; S.E.P., D.B., J.W.W., and S.K.R. analyzed data; S.E.P., D.B., and J.C. wrote the paper. Acknowledgements: This work was supported by NIH Grant MH076145 to J.C. We thank Danielle Letourneau for editorial assistance.

*S.E.P., A.H.Y., and D.M.B. contributed equally to this work.

The authors declare no competing financial interests.

Correspondence should be addressed to Jerold Chun, The Scripps Research Institute, 10550 North Torrey Pines Road, DNC-118/Chun, La Jolla, CA 92037. E-mail: jchun@scripps.edu.

S. E. Peterson's present address: Department of Chemical Physiology, The Scripps Research Institute, La Jolla, CA 92037.

A. H. Yang's present address: Pfizer, Inc., La Jolla, CA 92121

J. W. Westra's present address: Selventa, Cambridge, MA 02140.

S. Barral's present address: Miltenyi Biotec, Institut de Biologie du Développement de Marseille-Luminy, Marseille, France.

T. Mutoh's present address: Biological Sciences, Gunma Kokusai Academy Secondary School, Ota, Japan.

S. K. Rehen's present address: Institute of Biomedical Sciences, Federal University of Rio de Janiero, Rio de Janiero, Brazil.

DOI:10.1523/JNEUROSCI.3706-12.2012

Copyright $\odot 2012$ the authors $\quad 0270-6474 / 12 / 3216213-10 \$ 15.00 / 0$
}

NPCs can vary compared with euploid counterparts (Kaushal et al., 2003). As the brain matures, aneuploid karyotypes are maintained in postmitotic neurons and non-cycling glia, into adult life, as revealed by fluorescence in situ hybridization (FISH) (Rehen et al., 2001, 2005; Pack et al., 2005; Yurov et al., 2005; Kingsbury et al., 2006). Aneuploidies have clear consequences for cellular fitness, including decreasing the cell proliferation rate and causing protein level imbalances (Torres et al., 2007; Williams et al., 2008; Pavelka et al., 2010; Torres et al., 2010; Sheltzer and Amon, 2011); thus, integration of active aneuploid neurons into adult brain circuitry (Kingsbury et al., 2005) underscores their potential to affect brain function. Well-known constitutive aneuploidies (i.e., uniform organismal chromosomal gain) such as Trisomy 21, Down syndrome, have profound effects on CNS development and function (O'Doherty et al., 2005; Wiseman et al., 2009).

Despite these observations, proven functions of mosaic aneuploidy in the CNS are lacking. NPC aneuploidy correlates with neurogenesis (E12-E18 in the mouse) and programmed cell death (PCD) within the ventricular zone and subventricular zone of the embryonic cerebral cortex (Blaschke et al., 1996; Thomaidou et al., 1997; Weiner and Chun, 1997; Blaschke et al., 1998; Pompeiano et al., 2000; McConnell et al., 2009; Yung et al., 2009). PCD regulates cell number, cortical size and shape (Haydar et al., 1999; Kuan et al., 2000; Kingsbury et al., 2003; Rakic, 2005); an aneuploid karyotype could provide a cell-specific selective mechanism to drive the survival or death of an NPC. Developmental PCD, operating through apoptotic mechanisms, can be reduced in vivo by genetic deletion of either effector caspase-3, or the 
upstream initiator caspase-9, producing a severe neurodevelopmental phenotype characterized by exencephaly, expansion of the ventricular zone, neuronal hyperplasia and early postnatal death (Kuida et al., 1996, 1998; Hakem et al., 1998; Pompeiano et al., 2000; Oppenheim et al., 2001; Leonard et al., 2002; Momoi et al., 2003).

Here we report the effects on aneuploidy in mitotic cortical cells, including NPCs, following inhibition of caspase-mediated PCD: suppressing PCD leads to markedly increased levels of overall aneuploidy in mitotic and postmitotic cerebral cortical populations, including a preferential increase in extreme forms of aneuploidy that are rarely observed in wild-type cells while mild forms are relatively unaffected. These data indicate that caspasemediated PCD differentially affects aneuploid neural populations, supporting a mechanism of neural cell selection based upon somatically generated mosaic aneuploidy.

\section{Materials and Methods}

Animals and tissue collection. Caspase- $3^{+/-}$and caspase- $9^{+/-}$mice (Mus musculus) in a C57BL/6J background (Jackson Laboratories) were a generous gift from R. A. Flavell (Yale School of Medicine, New Haven, CT), and were expanded in-house. Mutants were also backcrossed onto a 129S1/SvlmJ background (Jackson Laboratories) for 6 or more generations. Timed-pregnant mice were killed by deep anesthesia followed by cervical dislocation and embryos rapidly removed at E14 for analysis of mitotic cells or E19 for postmitotic cells. Both background strains were examined and demonstrated consistent shifts in aneuploid populations; presented data are from mice of the 129S1/SvlmJ background. These caspase-null embryos displayed the most extreme forms of neuronal hyperplasia characterized by exencephaly produced by reduced cell death, as originally reported (Kuida et al., 1996, 1998). All animal protocols were approved by the Institutional Animal Care and Use Committee at The Scripps Research Institute (La Jolla, CA), and conform to the National Institutes of Health guidelines and public law.

Genotyping and sex determination. Caspase-3 embryos were genotyped using the following primers:

5'-GCGAGTGAGAATGTGCATAAATTC-3',

5'-GGGAAACCAACAGTAGTCAGTCCT-3',

5'-TGCTAAAGCGCATGCTCCAGACTG-3'. Caspase-9 embryos were genotyped using these primers: 5'-AGGCCAGCCACCTCCAGTTCC-3',

5' -CAGAGATGTGTAGAGAAGCCCACT-3' ${ }^{\prime}$ 5' -TCTCCTCTTCCT CATCTCCGGGCC-3' ${ }^{\prime}$ 5' -GAACAGTTCGGCTGGCGCGAGCCC-3' .

PCR conditions for both genotyping reactions were $94^{\circ} \mathrm{C}$ for $5 \mathrm{~min} ; 6$ cycles of $94^{\circ} \mathrm{C}$ for $30 \mathrm{~s}, 65^{\circ} \mathrm{C}$ for $30 \mathrm{~s}, 72^{\circ} \mathrm{C}$ for $1 \mathrm{~min} ; 30$ cycles of $94^{\circ} \mathrm{C}$ for $30 \mathrm{~s}, 58^{\circ} \mathrm{C}$ for $30 \mathrm{~s}, 72^{\circ} \mathrm{C}$ for $1 \mathrm{~min}$. Embryo sex was determined by Sry PCR, as previously described (Lambert et al., 2000). Female embryos were used exclusively for DNA content flow cytometry to control for genomic size differences between chromosomes $\mathrm{X}$ and $\mathrm{Y}$; embryos of both sexes were used for all other experiments, and were sex-matched to used wild-type controls.

$z V A D$-fmk treatment of ex vivo cortical hemispheres. Following isolation of E14 embryonic cerebral cortices, intact hemispheres were separated and incubated individually in OptiMem media (Life Technologies) containing $50 \mathrm{ng} / \mathrm{ml}$ basic fibroblast growth factor (Life Technologies) and either vehicle control [dimethyl sulfoxide (DMSO)] or $100 \mathrm{~nm}$ zVAD-fmk (Enzyme Systems Products) at $37^{\circ} \mathrm{C}, 5 \% \mathrm{CO}_{2}$ with gentle agitation (70-90 rpm) for up to $2 \mathrm{~d}$ as previously described (Kingsbury et al., 2003). Cortices were then prepared for sectioning and immunolabeling as described previously (Rehen et al., 2006) or for karyotype analysis as detailed below.

Metaphase spread preparation and spectral karyotyping. Preparation of E14 cortical cells for karyotyping was performed as previously described (Rehen et al., 2001). Briefly, freshly isolated cortices from wild-type and caspase-null mutant embryos were incubated with 100 ng/ml Karyomax Colcemid (Life Technologies) in OptiMem media for $3 \mathrm{~h}$ at $37^{\circ} \mathrm{C}$ with gentle agitation (70-90 rpm). Cortices were then triturated and centrifuged at $1000 \mathrm{rpm}$ for $5 \mathrm{~min}$ at $4^{\circ} \mathrm{C}$. Following media aspiration, cells were gently resuspended in $0.075 \mathrm{M} \mathrm{KCl}$ and incubated at $37^{\circ} \mathrm{C}$ for $7-10$ $\mathrm{min}$. Cells were then fixed in 3:1 methanol/glacial acetic acid, added dropwise while slowly vortexing. Metaphase spreads were prepared on Superfrost Plus slides (Fisher Scientific) following standard protocols (Barch et al., 1997). Spectral karyotyping (SKY) and 4',6-diamidino-2phenylindole (DAPI, Life Technologies) staining were performed according to manufacturer's instructions (Applied Spectral Imaging). Images of chromosome spreads were acquired using a Zeiss $63 \times$ or $100 \times$ objective with an interferometer and charge-coupled device camera (Applied Spectral Imaging). For DAPI counts, 100 metaphase spreads were analyzed per embryo, from three E14 litters of paired wild-type and caspase-3 or caspase-9-null embryos. For SKY analysis, $\sim 150$ spreads were analyzed from E14 wild-type, caspase-3, and caspase-9 embryos in the 129S1/SvlmJ background, and $\sim 250$ spreads were analyzed from embryos in the C57BL/6J background.

Fluorescence in situ hybridization. Interphase or non-mitotic nuclei from E19 wild-type, caspase-3, and caspase-9-null mutant embryos were harvested for FISH. Embryos were dissected and cortices sequentially triturated in cold PBS containing 2 mM EGTA, using p1000 tips with decreasing bore diameter, then filtered through a $40 \mu \mathrm{m}$ nylon filter. This filtered single cell suspension was centrifuged at $1000 \mathrm{rpm}$ for $5 \mathrm{~min}$ at $4^{\circ} \mathrm{C}$, then gently resuspended in cell lysis buffer $(10 \mathrm{~mm}$ Tris $\mathrm{Cl}, \mathrm{pH}$ 7.4, $3 \mathrm{~mm} \mathrm{CaCl}_{2}, 2 \mathrm{~mm} \mathrm{MgCl}, 1 \% \mathrm{NP}-40$ ) while slowly vortexing. Cells were lysed on ice for $5 \mathrm{~min}$, centrifuged again and resuspended in 3:1 methanol/glacial acetic acid fixative, then affixed to glass slides for hybridization. Prepared slides were pretreated with $50 \mu \mathrm{g} / \mathrm{ml}$ pep$\sin$ (Sigma-Aldrich) in $0.01 \mathrm{M} \mathrm{HCl}$ for $5 \mathrm{~min}$ at $37^{\circ} \mathrm{C}$, then sequentially incubated at room temperature with $50 \mathrm{mM} \mathrm{MgCl}_{2}$ in PBS for $5 \mathrm{~min}$, and $50 \mathrm{~mm} \mathrm{MgCl}_{2}$ with $1 \%$ formaldehyde in PBS for $10 \mathrm{~min}$. Slides were dehydrated and stored in a dessicator at $-20^{\circ} \mathrm{C}$ until use. FISH probes were generated using FISHTag kits for Alexa Fluor 488 and 555, according to the manufacturer's instructions (Life Technologies). Template DNA used for nick translation was obtained from the following BAC inserts: mouse chromosome 16 (RP23-99P18 and RP23-83P8), and mouse chromosome 8 (RP23-188E13) (CHORI). For hybridization, FISH probes were denatured at $80^{\circ} \mathrm{C}$ for $10 \mathrm{~min}$ then reannealed at $37^{\circ} \mathrm{C}$ for $60 \mathrm{~min}$. Slides were denatured at $75^{\circ} \mathrm{C}$ for $1.5 \mathrm{~min}$ in $2 \times$ SSC and $50 \%$ formamide, and immediately dehydrated. Probes were then applied to the slide on a coverslip, sealed with rubber cement and hybridized overnight at $37^{\circ} \mathrm{C}$. The following day, slides were washed at $45^{\circ} \mathrm{C}$ for $5 \mathrm{~min}$ each in $2 \times$ SSC with $50 \%$ formamide, $\mathrm{pH} 7.0,1 \times$ SSC, and $2 \times$ SSC with $0.1 \%$ Tween 20 . Finally, slides were stained with DAPI $(0.3 \mu \mathrm{g} / \mathrm{ml})$, dehydrated and mounted with a coverslip and Vectashield (Vector Labs). Three sets of E19 wild-type and caspase-null littermate cortices were analyzed for both caspase- 3 and caspase-9; between 2500 and 3500 nuclei from both background strains were analyzed per cortex per chromosome. Error rates for FISH probes were determined to be $<0.05 \%$ using metaphase spreads from lymphocyte controls.

DNA content analysis by flow cytometry. DNA content was determined as previously described (Capparelli et al., 1997; Rehen et al., 2001; Westra et al., 2010). Cells from isolated cortices were triturated to a single cell suspension as described above, then fixed in ice-cold $70 \%$ ethanol and stored at $-20^{\circ} \mathrm{C}$ until use. On the day of analysis, cells were washed with PBS then treated with RNase A $(40 \mu \mathrm{g} / \mathrm{ml})$ for $20 \mathrm{~min}$ at $37^{\circ} \mathrm{C}$. Cells were washed again with PBS and resuspended in a staining solution containing $50 \mu \mathrm{g} / \mathrm{ml}$ propidium iodide (Sigma-Aldrich) for 60-90 min. Each sample was spiked with chick erythrocyte nuclei (CEN) as an internal control (BioSure). Just before analysis, samples were filtered through a $40 \mu \mathrm{m}$ nylon filter. DNA content was then assessed with a FACSort flow cytometer (Becton Dickinson); 25,000-50,000 events were analyzed per sample. Relative DNA content was expressed as a ratio of the mean fluorescent intensity of the $G_{0} / G_{1}$ peak divided by that of the CEN peak. Three sets of wild-type and caspase-null sex-matched littermates for both caspase- 3 and caspase- 9 were used for DNA content comparisons; samples were processed blind to identity.

\section{Results}

To analyze neural aneuploidy in the embryonic cortex, four independent procedures were used: (1) DAPI staining of chromo- 
A

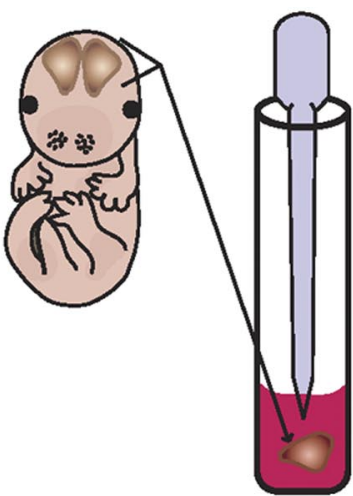

Isolate E14 cortex Triturate cells

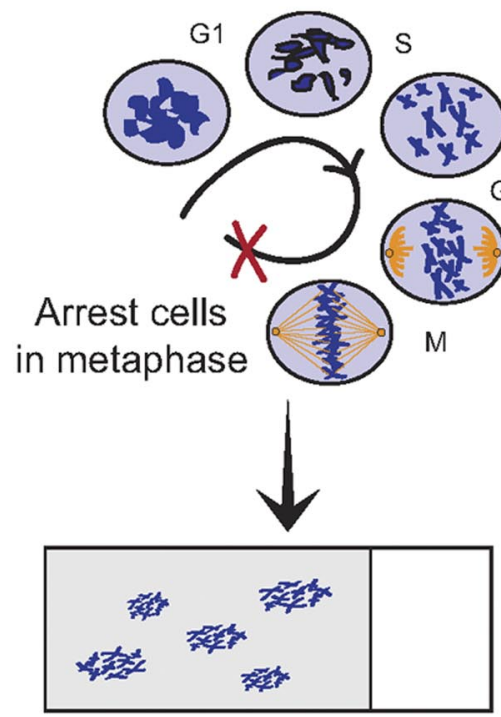

Make metaphase spreads

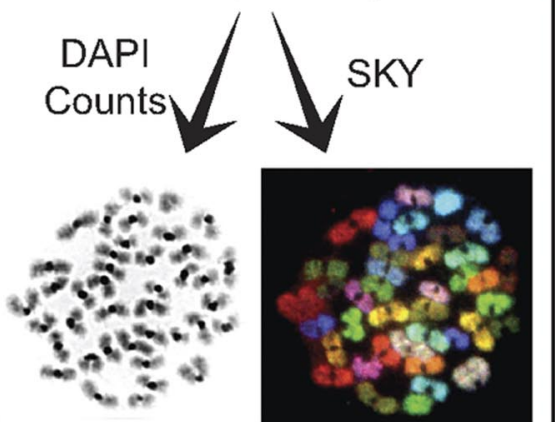

B

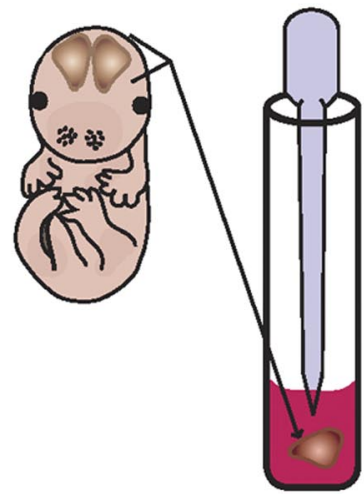

Isolate E14 cortex

Triturate cells

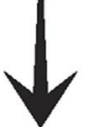

Fix cells and stain with fluorescent DNA dye

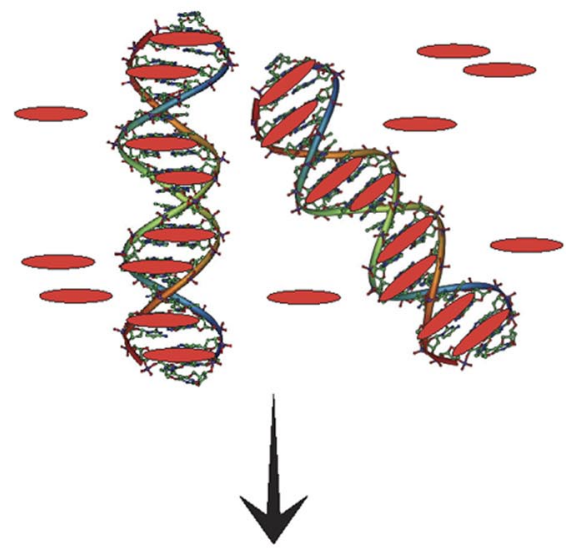

Analyze DNA content by flow cytometry

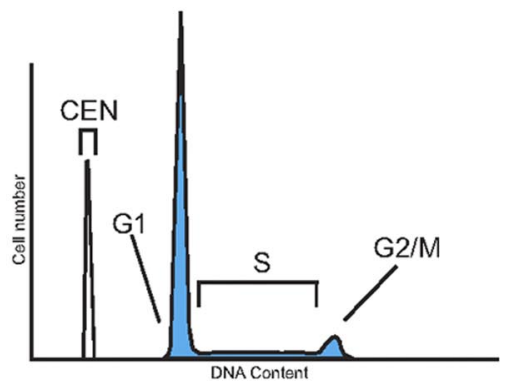

C

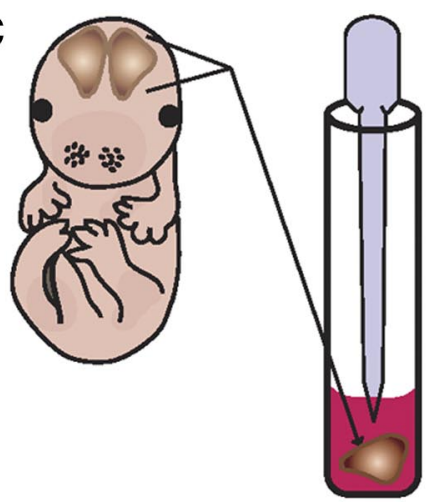

Isolate E19 cortex Triturate cells

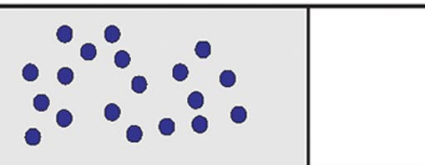

Isolate nuclei and place on slide<smiles>CCCC</smiles>

Hybridize with sequencespecific point probes

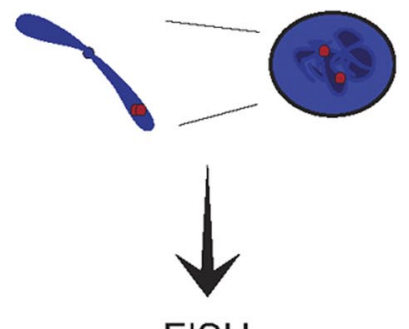

$\mathrm{FISH}$

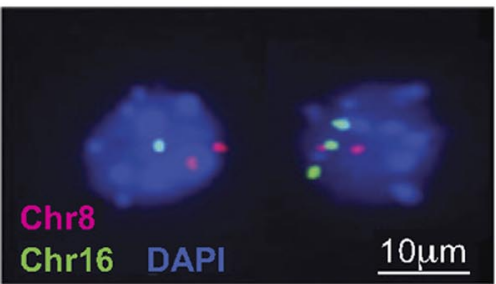

Figure 1. Schematic for analyzing aneuploidy in mitotic and non-mitotic cortical cells. $A$, Cortices were dissected from embryos at E14, triturated, and placed in culture in Colcemid ( $100 \mathrm{ng} / \mathrm{ml})$ to arrest cells in metaphase and obtain chromosome spreads. Each cell's chromosomal complement was analyzed in one of two ways. First, chromosomes were stained with DAPl and counted using fluorescence microscopy (bottom left). Second, metaphase chromosome spreads were processed for SKY to determine exact karyotypes (bottom right). B, E14 cortices were isolated, triturated, and fixed for staining with the DNA-intercalating dye Propidium lodide. Dye-saturated cells were analyzed by flow cytometry, where the dominant peak on a DNA content histogram contains cells in the $G_{0} / G_{1}$ phase of the cell cycle. Relative DNA content was expressed as a ratio of the mean fluorescent intensity of the $G_{0} / G_{1}$ peak divided by the peak of an internal standard, CEN. C, For analysis of interphase or non-mitotic cells, E19 cortices were triturated, cell nuclei were isolated, applied to a slide, and hybridized with chromosome-specific FISH probes. For these experiments, nuclei were hybridized with probes for chromosomes 16 (green) and 8 (red), and stained with DAPI (blue). Normal, euploid cells would be disomic for both chromosome 8 and 16 and thus would have 2 green dots and 2 red dots. The nucleus on the left is monosomic for chromosome 16 and the nucleus on the right is trisomic for chromosome 16, meaning both nuclei are aneuploid. Both nuclei are disomic for chromosome 8.

somes from mitotic cortical cells including NPCs; (2) SKY (Schröck et al., 1996) of chromosomes from mitotic cortical cells including NPCs; (3) DNA content analyses of non-mitotic cells; and (4) FISH of interphase or non-mitotic nuclei to assess spe- cific aneusomies (Fig. 1). A representative DAPI-stained mitotic cortical cell chromosome spread containing 38 chromosomes (Fig. 1A, DAPI) identifies an aneuploid cell (the euploid chromosome number for Mus musculus is 40). The complete karyo- 

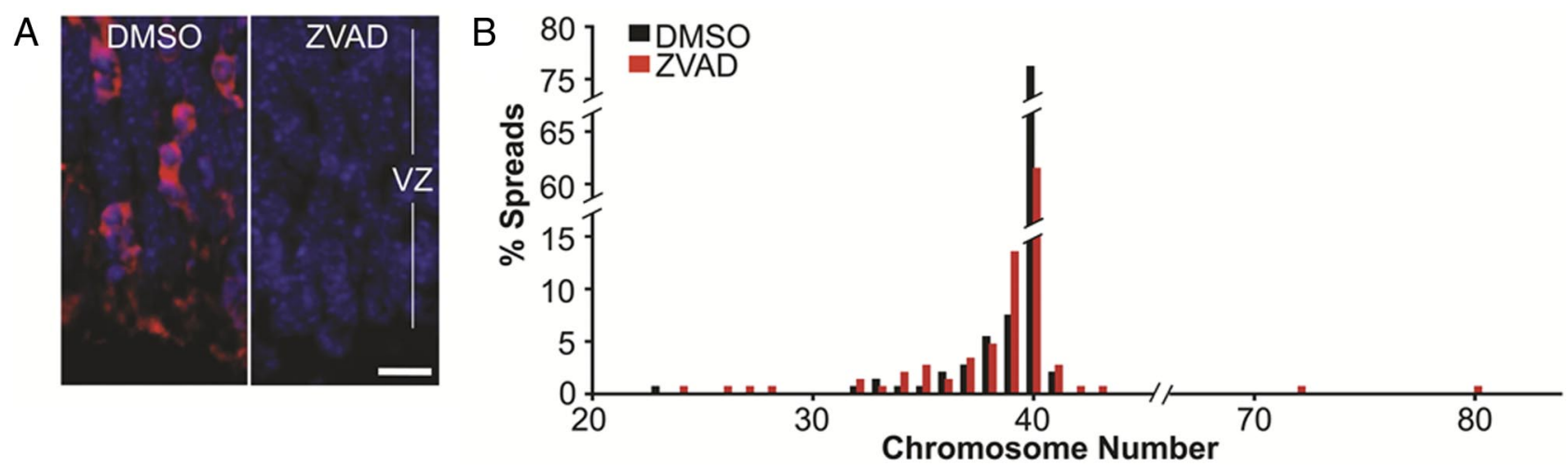

Figure 2. Pharmacological inhibition of caspases leads to increased aneuploidy in mitotic cells from the embryonic mouse cortex. $\boldsymbol{A}$, Intact hemispheres of E14 cortex were treated ex vivo with vehicle control (DMSO) or the pan caspase inhibitor zVAD-fmk (100 nM). DMSO-treated sections show high levels of immunoreactivity for cleaved caspase-3 (red), while those treated with zVAD-fmk showed markedly reduced immunoreactivity (from $15.3 \%$ to $0.4 \%$, respectively; $p=0.01$, Student's $t$ test). Tissues were counterstained with DAPI (blue). Scale bar, $20 \mu m$. VZ, Ventricular zone. $\boldsymbol{B}$, Histogram of the distribution of aneuploid cells identified following exposure of cortices to vehicle control (DMSO; black) and zVAD-fmk (red).

type of this spread was determined by SKY, where each chromosome is painted with a spectrally distinct combination of hybridized probes, identifying this cortical cell as 38, XY, -6, -13 (Fig. 1A, SKY). Non-mitotic cells (postmitotic neurons, non-cycling glia and interphase cells) do not produce condensed, metaphase chromosomes. These cells can be analyzed for chromosomal gains or losses by measuring DNA content (Fig. 1B), and by FISH, to identify aneusomic cells (cells that have gained or lost an assessed chromosome pair, albeit without knowledge of the remaining chromosomes) (Fig. 1C). These techniques were applied to wild-type versus experimental conditions in which PCD was attenuated through pharmacological inhibition or genetic deletion of caspases.

\section{Pharmacological inhibition of caspases increases aneuploidy levels}

The effects of pharmacological caspase inhibition on aneuploidy were assessed using ex vivo cortical cultures (Kingsbury et al., 2003; Rehen et al., 2006) exposed to the synthetic peptide, pancaspase inhibitor zVAD-fmk (benzyloxycarbonyl-Val-Ala-Aspfluoromethylketone) (Chow et al., 1995; Zhu et al., 1995; Slee et al., 1996). This cell-permeable, irreversible caspase inhibitor inactivates both initiator caspases (e.g., caspase-8 and -9) and effector caspases (e.g., caspase-3) (Armstrong et al., 1996; Sun et al., 1999; Lopez-Hernandez et al., 2003). Pharmacological inhibition by zVAD-fmk is not optimal for in vivo studies because of its cytotoxicity. However, ex vivo cortical hemisphere cultures retain normal organization and molecular processes observed in vivo, including interkinetic nuclear migration, DNA synthesis, and cell cycle progression (Kingsbury et al., 2003; Rehen et al., 2006), providing a model system to assess the effects of pharmacological caspase inhibition on mitotic cortical cell aneuploidy. In cortical hemispheres cultured in the presence of $100 \mathrm{~nm} z V A D-f m k, a$ significant reduction in activated caspase- 3 immunoreactivity occurs in the ventricular zone compared with the vehicle-treated control cortical hemispheres from the same embryos (Fig. $2 \mathrm{~A}$, from $15.3 \%$ in vehicle-treated samples to $0.4 \%$ in $\mathrm{zVAD}$-fmk cortices; $p=0.01$, Student's $t$ test). Mitotic cortical cell aneuploidy following zVAD-fmk exposure was therefore assessed by chromosome counts using the ex vivo system. A 58\% increase in aneuploidy was observed (Control $=24 \%$ aneuploidy; zVAD$\mathrm{fmk}=38 \% ; p=0.03$, Student's $t$ test). The increase in aneuploid cells following caspase inhibition was accompanied by a wider range of numerical aneuploidy forms in brains exposed to the caspase inhibitor (Fig. 2 B). This was also reflected in a higher SD from the mean chromosome number in zVAD-fmk-treated mitotic cortical cells. For all experimental and control conditions, both hypo- and hyperploid cells were observed; however, hypoploidy (i.e., having fewer than the euploid number of chromosomes) was the predominant form of aneuploidy recorded (Fig. $2 \mathrm{~B}$ ), which is consistent with in vivo observations of NPC aneuploidy (Rehen et al., 2001).

\section{Null mutants of caspase- 3 or caspase- 9 show increased aneuploidy in mitotic cortical cells}

To determine whether aneuploidy levels increased in vivo in the absence of caspase activity required for apoptosis, we assessed caspase-3 and caspase-9-null mutants. The ablation of either of these two caspases, both integral to cell-intrinsic apoptotic mechanisms, attenuates cell death and can produce hyperplasic brain growth by reducing cortical PCD (Kuida et al., 1996, 1998; Hakem et al., 1998; Rubenstein and Rakic, 1999). Mitotic cortical cells from caspase-3 and caspase-9-null homozygotes that showed enlarged brains were harvested for metaphase chromosome spread analysis. Compared with wild-type embryos which displayed 29\% aneuploidy, a respective $79 \%$ and $60 \%$ increase in aneuploidy was observed in mitotic cortical cells from caspase- 3 (50\% total aneuploidy) and caspase-9 (46\% aneuploidy) nulls (Fig. $3 A, p=0.02$ and $p=0.04$, respectively, Student's $t$ test). This increase in total aneuploidy was accompanied by an expanded range of numerically distinct aneuploidies identified in both caspase- 3 and caspase-9-null mutants (Fig. 3C), similar to that seen with ex vivo zVAD-fmk treatment. As with the wild-type mitotic cortical cells, aneuploidies in both of the caspase-null mutants were predominantly hypoploid. This effect was observed in both genetic backgrounds (data from the C57BL/6J background not shown).

Null mutants of caspase- 3 or caspase- 9 show decreased DNA content and increased aneusomy in non-mitotic cortical cells Independent support for the increased aneuploidy identified in metaphase chromosome spreads was obtained through examination of non-mitotic cells that do not have condensed chromosomes, using two distinct methodologies. First, DNA content was assessed in non-mitotic cells, similar to approaches previously used to identify aneuploidy in cancer specimens (Laerum and Farsund, 1981) and to identify different sex chromosomes in spermatozoa (Johnson, 1995). Caspase-3 and caspase-9-null cor- 


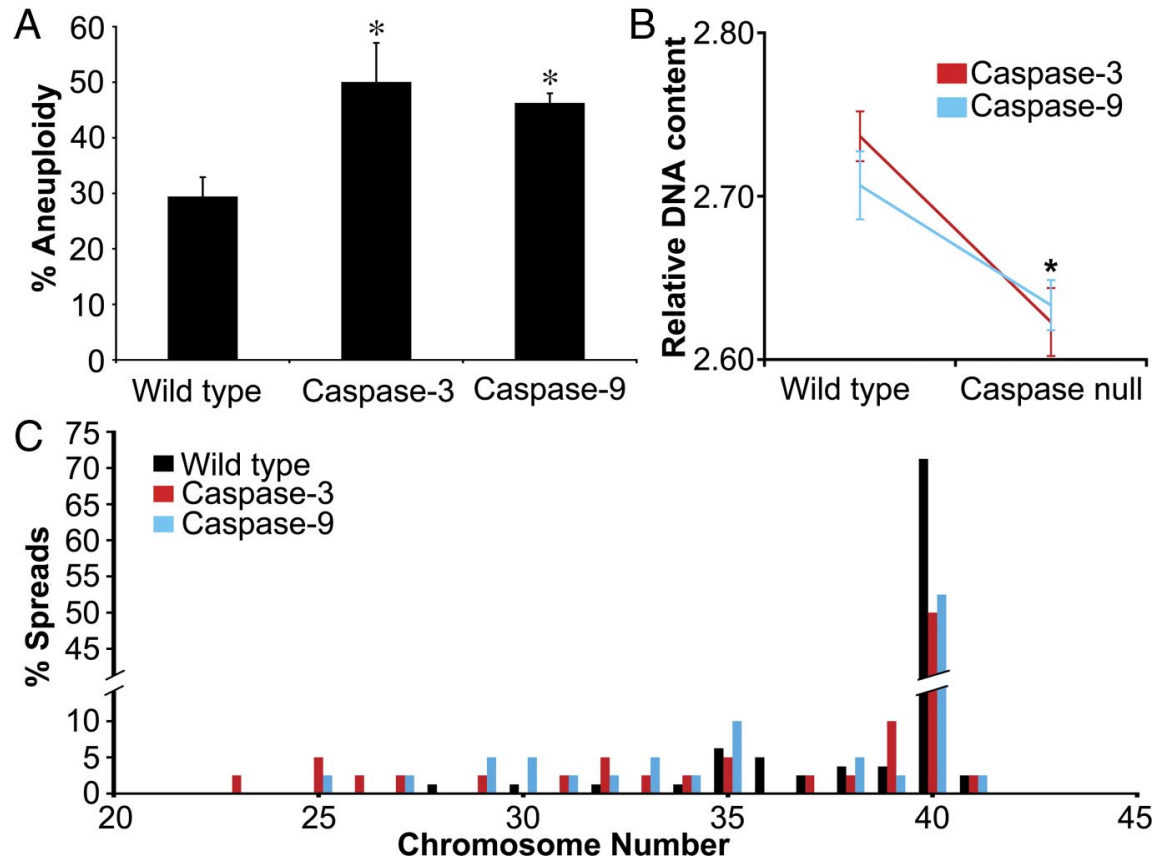

Figure 3. Genetic ablation of caspases leads to increased aneuploidy in mitotic cells from the embryonic mouse cortex. $\boldsymbol{A}$, Analysis of metaphase chromosome counts showed increased aneuploidy in E14 caspase-3 and caspase-9-null cortices compared with wild-type cortices from littermates ( 100 metaphase spreads were counted per embryo; for caspase-3, $n=3 ;{ }^{*} p=0.02$; for caspase-9, $n=3 ;{ }^{*} p=0.04$, Student's $t$ test). $B$, Quantitation of DNA content by flow cytometry showed a significant 3-4\% decrease in overall DNA content from cortices of E14 caspase nulls compared with sex-matched, wild-type littermates (caspase-3 wild-type and nulls, $n=4,{ }^{*} p=0.002$, Student's $t$ test; caspase-9 wild-type and nulls, $n=3,{ }^{*} p=0.03$, Student's $t$ test). $\boldsymbol{C}$, Histogram of the distribution of aneuploidy in E14 wild-type (black), caspase-3-null (red), and caspase-9-null (blue) NPCs. Caspase-deficient cells showed expanded distribution of numerical aneuploidies.

tices from E14 embryos were processed for DNA content analysis, wherein single-cell suspensions were stained with propidium iodide to determine DNA content by flow cytometry (Fig. $1 B$ ). As an internal standard, CEN were spiked into the preparation and processed simultaneously with all samples (Yu et al., 1993), followed by construction of DNA content histograms. The dominant peak on a DNA content histogram contains cells in the $\mathrm{G}_{0} / \mathrm{G}_{1}$ phase of the cell cycle, consisting of cells with diploid DNA content. Deviations in the $G_{0} / G_{1}$ peak relative to the internal control CEN peak were used to determine differences in relative DNA content, as reported previously (Westra et al., 2010). Cortical cells from both caspase-3 and caspase-9-null mutants showed a 3-4\% decrease in total DNA content compared with age- and sex-matched wild-type controls (Fig. $3 B, p=0.002$ and $p=0.03$, respectively, Student's $t$ test), consistent with increased hypoploidy. This decrease in DNA content was replicated using a distinct DNA dye, DAPI (data not shown).

DNA content analysis does not have the capacity to identify changes in specific chromosome pairs. To determine whether the changes in aneuploidy levels persist at later ages in postmitotic neurons and other non-mitotic cell populations that cannot be analyzed by metaphase spreads, individual chromosomes were interrogated using FISH (Fig. 1C). Cortical cells from E19 caspase-null mutants were compared with wild-type for the presence or absence of representative autosomes (chromosomes 8 and 16). A significant increase in overall aneusomy of chromosome 16 was observed in both caspase nulls compared with wildtype: caspase- 3 increased to $2.9 \%$ from $2.1 \%$ in wild-type, and caspase- 9 increased to $2.6 \%(n=3 ; p=0.0002$ and $p=0.004$ by $\chi^{2}$, respectively). A significant increase was also seen for chromosome 8 in caspase-3-null mutants, from $1.6 \%$ in wild-type to
$2.1 \%$ in the mutant $(n=3 ; p=0.04$ by $\chi^{2}$ ). It is important to note that aneusomy rates of $1-3 \%$ reflect interrogation of only a single chromosome pair, 1/20th of the total chromosomal complement, contrasting with the full karyotypic assessments achievable by metaphase spread counts.

Null mutants of caspase- 3 or caspase- 9 show increases in extreme aneuploidies Caspase inhibition by pharmacological means as well as through genetic deletion of either caspase- 3 or caspase- 9 increases the distribution of numerical aneuploidies observed in mitotic cortical cells. To determine the effects of PCD attenuation on karyotypes, one hundred aneuploid metaphase chromosome spreads from each of three litters containing agematched wild-type and caspase-null embryos were plotted as a histogram then arbitrarily divided into distinct bins designed to capture major effects on chromosome number within analyzed cells (Fig. $4 A, B$ ). Bin 1 represents "mild" aneuploidies where chromosome numbers flank the euploid chromosome number of 40 (light gray: 35-39 and 41-45 chromosomes). Bins 2 and 3 represent more "extreme" aneuploidies (bin 2, medium gray: 30-34 and 46-50 chromosomes; bin 3, black: $0-29$ and 51 or more). Compared with wild-type aneuploidy levels, caspase- 3 nulls displayed a significant increase in the percentage of cells with extreme aneuploidies: bin 2 increases from $2.5 \%$ in wild-type embryos to $12.5 \%$ in mutants, and bin 3 increases from $2.5 \%$ to $15 \%$ (Fig. $4 B, p<0.003$, Student's $t$ test). Caspase- 9 nulls displayed a similar trend, with bin 2 increasing from $5 \%$ to $17.5 \%$ and bin 3 from $0 \%$ in wild-type to $10 \%$ in nulls (Fig. $4 B, p<0.003$, Student's $t$ test). No statistically significant change in the percentage of cells with mild aneuploidies (bin 1) was observed, indicating that the increase in total aneuploidy was due to these extreme aneuploidies. The expansion of the extremely aneuploid population of mitotic cortical cells (bins 2 and 3 together) constituted over half of the caspase- 3 and -9 aneuploid populations. Note that the size of the entire pie represents the total amount of aneuploidy, resulting in larger pies produced following attenuated cell death compared with controls. Similar results were observed in caspase-null mutants on a C57BL/6J background (data not shown).

\section{Null mutants of caspase- 3 or caspase- 9 show increases in the} frequency of rare mitotic cell karyotypes

Numerical aneuploidies do not identify specific chromosomes that have been lost and/or gained. SKY was therefore used to assess karyotypic alterations. Coincident chromosomal gain and loss (Fig. 5A), as well as nullisomies, produced when both chromosomes of the same pair are lost (Fig. 5B) showed increased prevalence following caspase inhibition (Fig. $5 C-E$ ). In both caspase-null mutants, there was a marked increase in rare karyotypes (Fig. $5 F$ ): incidence of nullisomy increased from $5 \%$ in wild-type to $40 \%$ in caspase- 3 and $35 \%$ in caspase- 9 nulls $(p<$ $\left.0.05, \chi^{2}\right)$, while coincident gain and loss increased from $0 \%$ in 


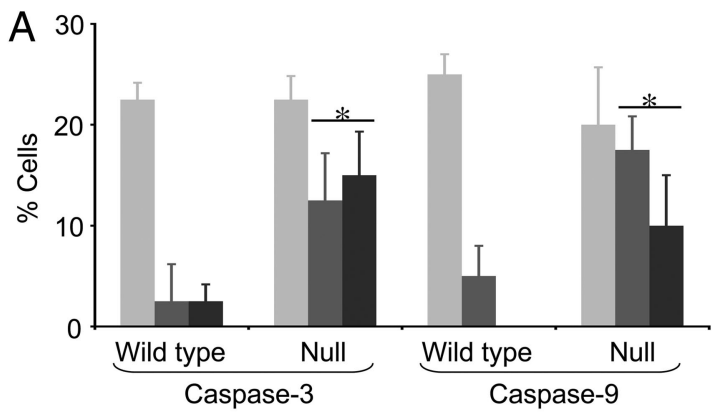

Bin 1, chromosome numbers 35-39, 41-45

Bin 2, chromosome numbers 30-34, 46-50

Bin 3, chromosome numbers $0-29,51-80$

\section{B}
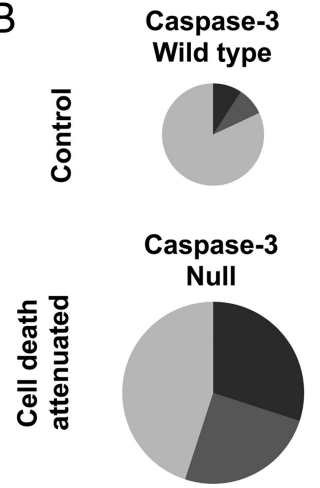

Figure 4. Caspase-attenuated mitotic cortical cells show an increase in extreme aneuploidy, while maintaining mild aneuploidy levels. $A, 0$ ne hundred aneuploid metaphase spreads were analyzed for each of 3 paired sets of wild-type and caspase-null littermates. Bin 1 represents mild aneuploidies where chromosome numbers flank the euploid chromosome number of 40 (light gray, 35-39 and 41-45 chromosomes). Bins 2 and 3 represent more extreme aneuploidies (bin 2: medium gray, 30-34 and 46-50 chromosomes; bin 3: black, $0-29$ and 51 or more). Euploid spreads are not shown. Caspase attenuation resulted in a preferential expansion of extreme aneuploidies (bins 2 and $3,{ }^{*} p<0.003$, Student's $t$ test); no significant change was observed in cells showing mild aneuploidies (bin 1). B, Pie charts of mild and extreme aneuploidies from control versus caspase-null cortices were constructed to reflect relative percentages of cells in each bin (pie slice, colors as in Fig. $4 A$ ), and percentage of total aneuploidy (pie area). Pronounced expansion of bins 2 and 3 by percentage were coincident with PCD attenuation.

wild-type to $30 \%$ in caspase- 3 and $35 \%$ in caspase- 9 nulls $(p<$ $\left.0.03, \chi^{2}\right)$. Similar trends were observed in both genetic backgrounds (data from the C57BL/6J background not shown).

\section{Discussion}

Over the past decade, the initially surprising existence of mosaic aneuploidy within the CNS has now been verified in vertebrates from fish to humans (Rehen et al., 2001; Pack et al., 2005; Rehen et al., 2005; Yurov et al., 2005; Rajendran et al., 2007, 2008; Yurov et al., 2007; Westra et al., 2008; Iourov et al., 2009; Zupanc et al., 2009). By contrast, the functions of these diverse, mosaic aneuploidies remain unknown. Here we report the essential regulation of mosaic neural aneuploidies by cell death pathways during the development of the embryonic brain, suggesting that without tight molecular constraints, somatically generated genomic alterations may have severe functional consequences for neural development. These conclusions are derived from attenuating cell death among mitotic cortical cells through both pharmacological and genetic perturbations of well defined cell death mediatorscaspases 3 and 9-resulting in: (1) marked elevations of the total aneuploid cell population; (2) increases in the range of numerically diverse aneuploid cells; (3) differential increases in extreme aneuploidies over mild aneuploidies; and (4) increases in rare karyotypes defined by nullisomies as well as coincident gain and loss of chromosomes. These results indicate that inhibition of neural PCD not only increases cell number-as expected-but also increases the range and forms of genomically distinct cells that comprise the brain. These changes in mosaic aneuploidies may also contribute functionally to the phenotypic lethality observed in some caspase-null mutants (Kuida et al., 1996, 1998).

Our data are consistent with prevailing views on the functions of caspases, particularly caspases-3 and -9, in PCD. Caspasedependent intrinsic apoptosis, which involves activation of caspase- 9 and subsequently caspase- 3 by the release of mitochondrial outer membrane proteins (MOMPs) including cytochrome c (Garrido et al., 2006; Gogvadze et al., 2006; Ow et al., 2008; Galluzzi et al., 2012), underscores the sequential positioning of caspases along the same molecular death pathway. The similar results obtained using independent means of interrupting this pathway-pharmacological inhibition, caspase-3 or caspase- 9 genetic deletion-strongly support the effects on aneuploid populations as being due to reductions in caspase-mediated PCD. Notably, the overall effect of caspase inhibition was to increase total cell number (Fig. 4), as would be expected after inhibiting PCD (Kuida et al., 1996, 1998). Moreover, each of the three independent means of reducing caspase activity produced the same general result of expanding the distributions and extreme forms of aneuploidy-including both hypo- and hyperploidies-yet left intact distributions of mild aneuploid populations.

Caspase-mediated PCD is not the only form of cell death operating in the developing cerebral cortex. Mitotic catastrophe, as noted by the 2012 Nomenclature Committee on Cell Death, may have prominent roles in PCD of mitotic cortical cells, serving as an oncosuppressive mechanism triggered during $\mathrm{M}$ phase by a heterogeneous group of stimuli (Galluzzi et al., 2012). It also shares many hallmarks of apoptosis, including the MOMP release, and mitotic errors resulting in premature or inappropriate entry into mitosis (King and Cidlowski, 1995; Castedo et al., 2004; Bröker et al., 2005; Vakifahmetoglu et al., 2008a; Vitale et al., 2011; Galluzzi et al., 2012). Processes like necrosis may also contribute to cortical cell death (Vakifahmetoglu et al., 2008b), as could the actions of other caspases. Less than half of the observed cell death in the embryonic cortex is mediated by caspase- 3 (Pompeiano et al., 2000), indicating that other forms of PCD may contribute to the mosaically aneuploid landscape. These considerations suggest that the shifts in affected aneuploidies reported in this study would underestimate the genotypic diversity initially generated among mitotic cortical cells, including neural progenitor cells.

Aneuploidy produced by chromosome loss or gain is known to alter gene expression (Phillips et al., 2001; Kaushal et al., 2003; Torres et al., 2007). The dramatic increases in aneuploidy and the rare karyotypes - the coincident loss and gain of chromosomes, and nullisomies - that we observed in caspase-null mutants are virtually certain to vary the gene expression patterns within each affected cell. Variation of gene expression has consequences for both cell autonomous and non-cell autonomous activities, and implies phenotypic mosaicism that tracks with genotypic mosaicism throughout the brain. To this end, a most extreme, functional outcome of karyotypic diversity may be a "better dead than wrong" response (Zheng and Flavell, 1999). This response has been related to possible oncosuppressive roles of karyotype regulation by caspases in progenitor cells, which has broader implications for other endogenous and cultured stem cell populations, including their therapeutic use. While cancers have long been 
A Coincident gain and loss (38, XX, $+7,-8,-14,-18)$
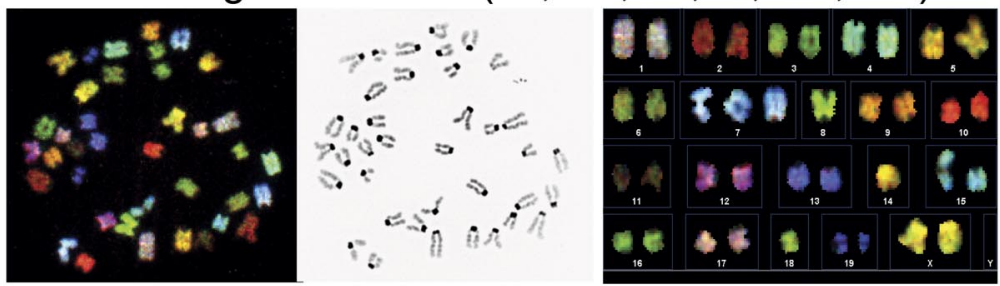

$\mathrm{B}$

Nullisomy $(33, \mathrm{XX},-11,-13,-14,-16,-18,-18,-19)$

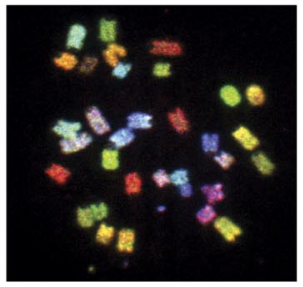

8.80

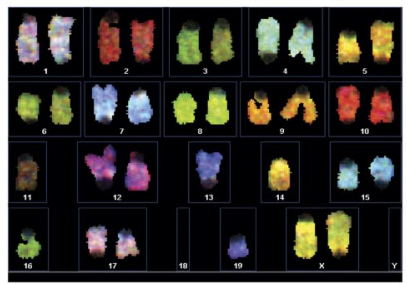

C

Wild type

D

Caspase-3
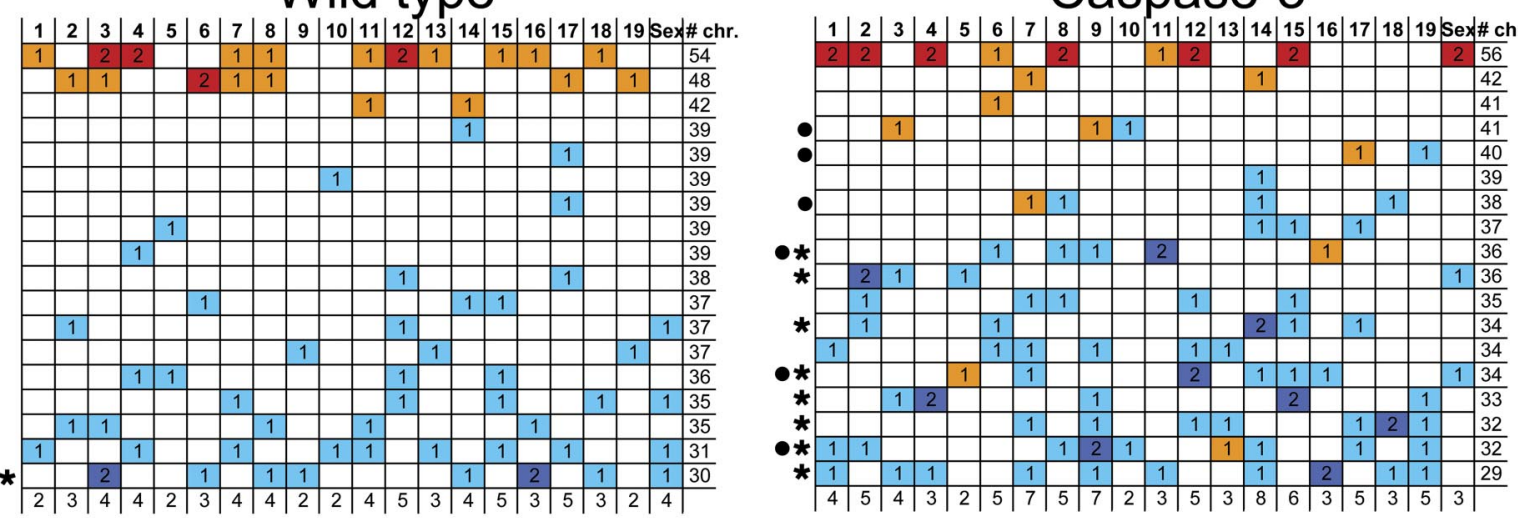

E
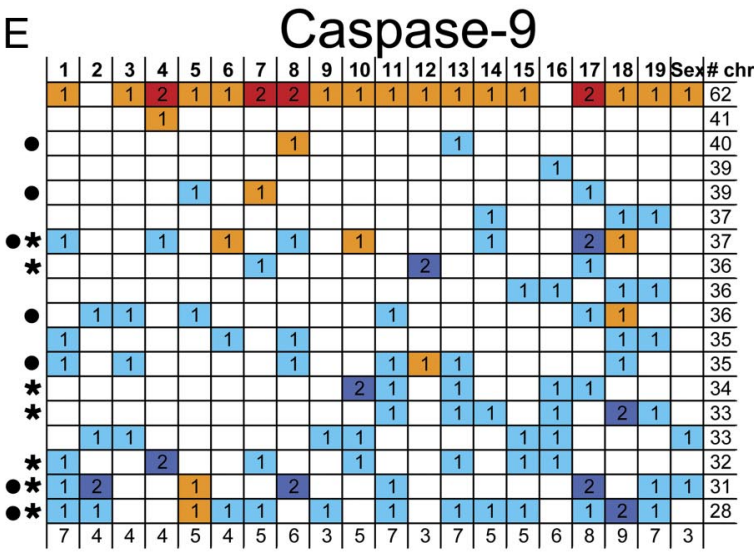
1 Gain of one chromosome
Gain of a chromosome pair
1 Loss of one chromosome
2 Loss of a chromosome pair (nullisomy)
* = nullisomy
- = coincident gain and loss

F

$\left.\begin{array}{lcc}\hline & \text { Nullisomy } & \text { Coincident gain and loss } \\ \hline \text { Wild type } & 5 \% \\ \text { Caspase-3 null } & 40 \% \\ \text { Caspase-9 null } & 35 \%\end{array}\right] * \begin{gathered}0 \% \\ { }^{*} P<0.05, \text { chi square }\end{gathered}$

${ }^{*} P<0.05$, chi square

** $P<0.03$, chi square

Figure 5. Caspase attenuation increases rare aneuploidies including nullisomy and coincident chromosomal gain and loss, identified by SKY. $\boldsymbol{A}, \boldsymbol{B}$, Representative metaphase spreads from E14 caspase-3-null cortices analyzed by SKY showing coincident chromosome gain and loss $(\boldsymbol{A})$ and nullisomy $(\boldsymbol{B})$. SKY analyses of each cell included pseudocolor chromosome spread (left), DAPI counterstain (middle), and karyotype table (right). $\boldsymbol{C}-\boldsymbol{E}$, Tabular representation of 20 aneuploid karyotypes from E14 wild-type (C), caspase-3-null (D) and caspase-9-null (E) mitotic cortical cells. Chromosome numbers are indicated across the top row. Each row below shows the karyotype of an individual aneuploid cortical cell. The rightmost column indicates the total number of chromosomes in each spread. The last row reports the number of times a chromosome is involved in a gain or loss event. Orange squares, gain of one chromosome; red squares, gain of a chromosome pair; light blue squares, loss of one chromosome; deep blue squares, loss of a chromosome pair (i.e., nullisomy). Spreads containing a nullisomy and/or coincident chromosomal gain and loss are indicated with stars and circles, respectively, along the left most column. $\boldsymbol{F}$, Frequencies of nullisomy and coincident gain and loss of chromosomes among wild-type, caspase-3 and caspase-9-null aneuploid cortical cells. ${ }^{*} p<0.05, \chi^{2}$ for nullisomy; $p<0.03, \chi^{2}$ for coincident loss and gain.

reported to contain characteristic aneuploidies, particularly hyperploidies (Lengauer et al., 1997, 1998; Rajagopalan and Lengauer, 2004), more recent studies present evidence for both mosaic and constitutive aneuploidies in cultured stem cell populations as well (Cervantes et al., 2002; Draper et al., 2004; Spits et al., 2008; Peterson et al., 2011). Karyotypic mosaicism is prominent in commonly used human stem cell lines (Peterson et al., 2011), which may reflect the normal, biological mosaicism observed in vivo in mitotic cortical cells including NPCs. It is possible that the increased prevalence of rare karyotypes observed here 
could have an increased oncogenic potential that accompanies gene expression abnormalities. Thus, putative neuroprotective agents, such as caspase inhibitors and growth factors, for treating neurodegeneration and ischemic brain injury (Deshmukh, 1998; Tai and Svendsen, 2004) may inadvertently alter the genomic composition of endogenous or transplanted cell populations. Such hypothetical effects deserve further study.

The mechanisms underlying the generation and subsequent loss or maintenance of the different aneuploid populations observed here are not completely understood. The generation of neural aneuploidy involves known chromosome missegregation mechanisms (Yang et al., 2003) that occur concomitantly with PCD (Blaschke et al., 1996, 1998; Staley et al., 1997; Pompeiano et al., 2000). Factors that might contribute to both the generation of aneuploidy and PCD may involve other forms of genomic variation within neural cells. Several proteins in the nonhomologous end joining pathway that includes the proteins XRCC4, DNA Ligase IV and $\mathrm{Ku}$, can produce extensive NPC apoptosis in the CNS (Barnes et al., 1998; Gao et al., 1998; Gu et al., 2000), as can other DNA modifying molecules (McConnell et al., 2004). In addition, LINE-1 (long interspersed element-1) retrotransposons may be active within neuronal populations, introducing further genomic heterogeneity (Muotri et al., 2005; Muotri and Gage, 2006). These genome-altering phenomena are members of a superset of genomic changes identified within brain cells, referred to as DNA content variation (DCV) (Westra et al., 2010). In view of the data presented here, forms of DCV may serve as a basis for cell selection, reminiscent of the immune system that relies on genomic changes associated with antigen receptor DNA rearrangements (affecting T-cell receptors and immunoglobulins), which results in positive and negative selection, as well as death by neglect (Chun, 2001; Malu et al., 2012).

These results add a new dimension to the consequences of PCD and its perturbation during the development of the embryonic cerebral cortex (Blaschke et al., 1996; Kuida et al., 1996, 1998; Hakem et al., 1998; Yoshida et al., 1998; Pompeiano et al., 2000; Wilkie et al., 2004), wherein PCD shapes not only cell number, but also shapes the mosaic genomic landscape of the brain. In this view, cells with undesirable karyotypes are normally eliminated, contrasting with desirable karyotypes - including euploid cells — that are maintained (Fig. 6). The need for cell selection to produce this complex mix of karyotypic diversity may in part explain neural proliferative cell death occurring during cortical neurogenesis as well as within other zones of neuroproliferation (Blaschke et al., 1996, 1998; Yung et al., 2009). Our data highlight the functional non-equivalence of different karyotypes in PCD and cell survival, since mild aneuploidies are relatively preserved over extreme forms, and this non-
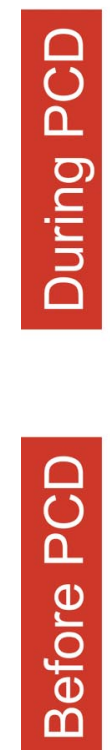

Wild type
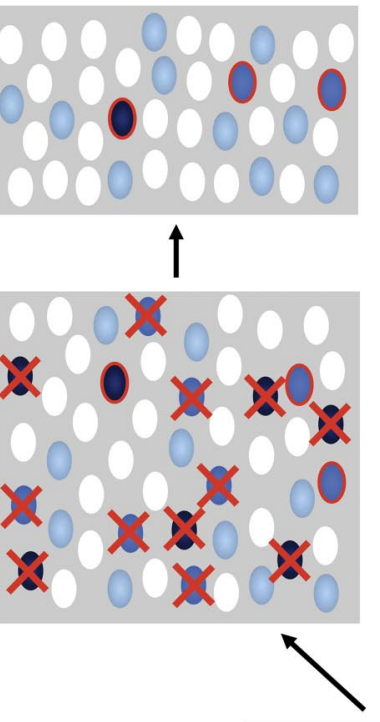

Cell death attenuated

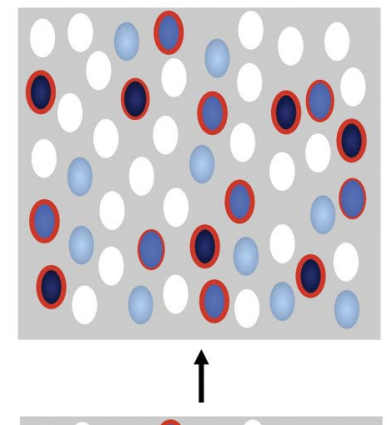

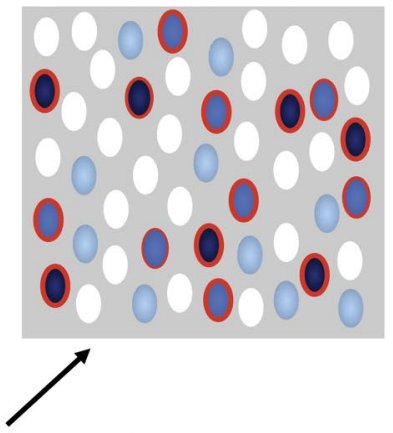

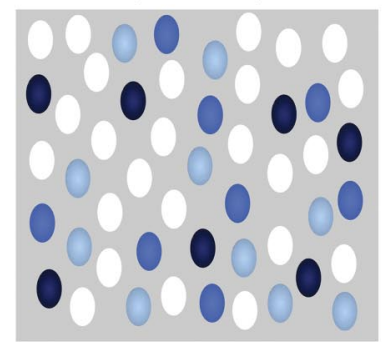

$\mathrm{X}=$ Eliminated extremely aneuploid cell

0 = Preserved extremely aneuploid cell

\section{Bin 0, Euploid}

Bin 1, chromosome numbers 35-39, 41-45

$$
\left.\begin{array}{l}
\text { Bin 2, chromosome numbers } 30-34,46-50 \\
\text { Bin 3, chromosome numbers 0-29, 51-80 }
\end{array}\right] \begin{gathered}
\text { Extreme } \\
\text { aneuploidy }
\end{gathered}
$$

Figure 6. Model of aneuploidy-based selection in the developing cerebral cortex. The normal pathway (wild-type) is compared with experimental manipulation using inhibition of caspase activity (cell death attenuated). Both mild and extremely aneuploid cells (compare Fig. 4) are generated during neurogenesis (Before PCD) to produce a mosaic of intermixed euploid and aneuploid cortical cells. During PCD, extremely aneuploid cells are normally eliminated (red X), but when caspase-mediated PCD is attenuated, these cells are preserved (red outline). In the wild-type brain (After PCD), most cells are either euploid or mildly aneuploid. When PCD is attenuated, however, the brain becomes populated by more extremely aneuploid cells.

equivalence may extend to other aspects of functionality. This mélange of mosaic aneuploidies intermixed with euploid cells may also be altered with respect to form, number, and neuroanatomical organization. We speculate that developmental perturbations to normal mosaicism-through genetic mechanisms as noted here, as well as myriad environmental insults - could contribute to variation in complex neural traits and to brain disorders (Dykens et al., 2004; Kingsbury et al., 2006).

\section{References}

Armstrong RC, Aja T, Xiang J, Gaur S, Krebs JF, Hoang K, Bai X, Korsmeyer SJ, Karanewsky DS, Fritz LC, Tomaselli KJ (1996) Fas-induced activation of the cell death-related protease CPP32 Is inhibited by Bcl-2 and by 
ICE family protease inhibitors. J Biol Chem 271:16850-16855. CrossRef Medline

Barch MJ, Knutsen T, and Spurbeck JL (1997) The AGT cytogenetics laboratory manual Philadelphia: Lippincott.

Barnes DE, Stamp G, Rosewell I, Denzel A, Lindahl T (1998) Targeted disruption of the gene encoding DNA ligase IV leads to lethality in embryonic mice. Curr Biol 8:1395-1398. CrossRef Medline

Blaschke AJ, Staley K, Chun J (1996) Widespread programmed cell death in proliferative and postmitotic regions of the fetal cerebral cortex. Development 122:1165-1174. Medline

Blaschke AJ, Weiner JA, Chun J (1998) Programmed cell death is a universal feature of embryonic and postnatal neuroproliferative regions throughout the central nervous system. J Comp Neurol 396:39-50. CrossRef Medline

Bröker LE, Kruyt FA, Giaccone G (2005) Cell death independent of caspases: a review. Clin Cancer Res 11:3155-3162. CrossRef Medline

Capparelli R, Cottone C, D’Apice L, Viscardi M, Colantonio L, Lucretti S, Iannelli D (1997) DNA content differences in laboratory mouse strains determined by flow cytometry. Cytometry 29:261-266. CrossRef Medline

Castedo M, Perfettini JL, Roumier T, Valent A, Raslova H, Yakushijin K, Horne D, Feunteun J, Lenoir G, Medema R, Vainchenker W, Kroemer G (2004) Mitotic catastrophe constitutes a special case of apoptosis whose suppression entails aneuploidy. Oncogene 23:4362-4370. CrossRef Medline

Cervantes RB, Stringer JR, Shao C, Tischfield JA, Stambrook PJ (2002) Embryonic stem cells and somatic cells differ in mutation frequency and type. Proc Natl Acad Sci U S A 99:3586-3590. CrossRef Medline

Chow SC, Weis M, Kass GE, Holmström TH, Eriksson JE, Orrenius S (1995) Involvement of multiple proteases during Fas-mediated apoptosis in $\mathrm{T}$ lymphocytes. FEBS Lett 364:134-138. CrossRef Medline

Chun J (2001) Selected comparison of immune and nervous system development. Adv Immunol 77:297-322. CrossRef Medline

Deshmukh M (1998) Caspases in ischaemic brain injury and neurodegenerative disease. Apoptosis 3:387-394. CrossRef Medline

Draper JS, Smith K, Gokhale P, Moore HD, Maltby E, Johnson J, Meisner L, Zwaka TP, Thomson JA, Andrews PW (2004) Recurrent gain of chromosomes $17 \mathrm{q}$ and 12 in cultured human embryonic stem cells. Nat Biotechnol 22:53-54. CrossRef Medline

Dykens EM, Sutcliffe JS, Levitt P (2004) Autism and 15q11-q13 disorders: behavioral, genetic, and pathophysiological issues. Ment Retard Dev Disabil Res Rev 10:284-291. CrossRef Medline

Galluzzi L, Vitale I, Abrams JM, Alnemri ES, Baehrecke EH, Blagosklonny MV, Dawson TM, Dawson VL, El-Deiry WS, Fulda S, Gottlieb E, Green DR, Hengartner MO, Kepp O, Knight RA, Kumar S, Lipton SA, Lu X, Madeo F, Malorni W, et al. (2012) Molecular definitions of cell death subroutines: recommendations of the Nomenclature Committee on Cell Death 2012. Cell Death Differ 19:107-120. CrossRef Medline

Gao Y, Sun Y, Frank KM, Dikkes P, Fujiwara Y, Seidl KJ, Sekiguchi JM, Rathbun GA, Swat W, Wang J, Bronson RT, Malynn BA, Bryans M, Zhu C, Chaudhuri J, Davidson L, Ferrini R, Stamato T, Orkin SH, Greenberg ME, Alt FW (1998) A critical role for DNA end-joining proteins in both lymphogenesis and neurogenesis. Cell 95:891-902. CrossRef Medline

Garrido C, Galluzzi L, Brunet M, Puig PE, Didelot C, Kroemer G (2006) Mechanisms of cytochrome c release from mitochondria. Cell Death Differ 13:1423-1433. CrossRef Medline

Gogvadze V, Orrenius S, Zhivotovsky B (2006) Multiple pathways of cytochrome $\mathrm{c}$ release from mitochondria in apoptosis. Biochim Biophys Acta 1757:639-647. CrossRef Medline

Gu Y, Sekiguchi J, Gao Y, Dikkes P, Frank K, Ferguson D, Hasty P, Chun J, Alt FW (2000) Defective embryonic neurogenesis in Ku-deficient but not DNA-dependent protein kinase catalytic subunit-deficient mice. Proc Natl Acad Sci U S A 97:2668-2673. CrossRef Medline

Hakem R, Hakem A, Duncan GS, Henderson JT, Woo M, Soengas MS, Elia A, de la Pompa JL, Kagi D, Khoo W, Potter J, Yoshida R, Kaufman SA, Lowe SW, Penninger JM, Mak TW (1998) Differential requirement for caspase 9 in apoptotic pathways in vivo. Cell 94:339-352. CrossRef Medline

Haydar TF, Kuan CY, Flavell RA, Rakic P (1999) The role of cell death in regulating the size and shape of the mammalian forebrain. Cereb Cortex 9:621-626. CrossRef Medline

Iourov IY, Vorsanova SG, Liehr T, Yurov YB (2009) Aneuploidy in the normal, Alzheimer's disease and ataxia-telangiectasia brain: differential ex- pression and pathological meaning. Neurobiol Dis 34:212-220. CrossRef Medline

Johnson LA (1995) Sex preselection by flow cytometric separation of X and $\mathrm{Y}$ chromosome-bearing sperm based on DNA difference: a review. Reprod Fertil Dev 7:893-903. CrossRef Medline

Kaushal D, Contos JJ, Treuner K, Yang AH, Kingsbury MA, Rehen SK, McConnell MJ, Okabe M, Barlow C, Chun J (2003) Alteration of gene expression by chromosome loss in the postnatal mouse brain. J Neurosci 23:5599-5606. Medline

King KL, Cidlowski JA (1995) Cell cycle and apoptosis: common pathways to life and death. J Cell Biochem 58:175-180. CrossRef Medline

Kingsbury MA, Rehen SK, Contos JJ, Higgins CM, Chun J (2003) Nonproliferative effects of lysophosphatidic acid enhance cortical growth and folding. Nat Neurosci 6:1292-1299. CrossRef Medline

Kingsbury MA, Friedman B, McConnell MJ, Rehen SK, Yang AH, Kaushal D, Chun J (2005) Aneuploid neurons are functionally active and integrated into brain circuitry. Proc Natl Acad Sci U S A 102:6143-6147. CrossRef Medline

Kingsbury MA, Yung YC, Peterson SE, Westra JW, Chun J (2006) Aneuploidy in the normal and diseased brain. Cell Mol Life Sci 63:2626-2641. CrossRef Medline

Kuan CY, Roth KA, Flavell RA, Rakic P (2000) Mechanisms of programmed cell death in the developing brain. Trends Neurosci 23:291-297. CrossRef Medline

Kuida K, Zheng TS, Na S, Kuan C, Yang D, Karasuyama H, Rakic P, Flavell RA (1996) Decreased apoptosis in the brain and premature lethality in CPP32-deficient mice. Nature 384:368-372. CrossRef Medline

Kuida K, Haydar TF, Kuan CY, Gu Y, Taya C, Karasuyama H, Su MS, Rakic P, Flavell RA (1998) Reduced apoptosis and cytochrome c-mediated caspase activation in mice lacking caspase 9. Cell 94:325-337. CrossRef Medline

Laerum OD, Farsund T (1981) Clinical application of flow cytometry: a review. Cytometry 2:1-13. CrossRef Medline

Lambert JF, Benoit BO, Colvin GA, Carlson J, Delville Y, Quesenberry PJ (2000) Quick sex determination of mouse fetuses. J Neurosci Methods 95:127-132. CrossRef Medline

Lengauer C, Kinzler KW, Vogelstein B (1997) Genetic instability in colorectal cancers. Nature 386:623-627. CrossRef Medline

Lengauer C, Kinzler KW, Vogelstein B (1998) Genetic instabilities in human cancers. Nature 396:643-649. CrossRef Medline

Leonard JR, Klocke BJ, D'Sa C, Flavell RA, Roth KA (2002) Straindependent neurodevelopmental abnormalities in caspase-3-deficient mice. J Neuropathol Exp Neurol 61:673-677. Medline

Lopez-Hernandez FJ, Ortiz MA, Bayon Y, Piedrafita FJ (2003) Z-FA-fmk inhibits effector caspases but not initiator caspases 8 and 10, and demonstrates that novel anticancer retinoid-related molecules induce apoptosis via the intrinsic pathway. Mol Cancer Ther 2:255-263. Medline

Malu S, Malshetty V, Francis D, Cortes P (2012) Role of non-homologous end joining in $\mathrm{V}(\mathrm{D}) \mathrm{J}$ recombination. Advance online publication. Retrieved June 11, 2012. Immunol Res. doi:10.1007/s12026-012-8329-z. CrossRef

McConnell MJ, Kaushal D, Yang AH, Kingsbury MA, Rehen SK, Treuner K, Helton R, Annas EG, Chun J, Barlow C (2004) Failed clearance of aneuploid embryonic neural progenitor cells leads to excess aneuploidy in the Atm-deficient but not the Trp53-deficient adult cerebral cortex. J Neurosci 24:8090-8096. CrossRef Medline

McConnell MJ, MacMillan HR, Chun J (2009) Mathematical modeling supports substantial mouse neural progenitor cell death. Neural Dev 4:28. CrossRef Medline

Momoi T, Fujita E, Urase K (2003) Strain-specific caspase-3-dependent programmed cell death in the early developing mouse forebrain. Neuroreport 14:111-115. CrossRef Medline

Muotri AR, Gage FH (2006) Generation of neuronal variability and complexity. Nature 441:1087-1093. CrossRef Medline

Muotri AR, Chu VT, Marchetto MC, Deng W, Moran JV, Gage FH (2005) Somatic mosaicism in neuronal precursor cells mediated by L1 retrotransposition. Nature 435:903-910. CrossRef Medline

O’Doherty A, Ruf S, Mulligan C, Hildreth V, Errington ML, Cooke S, Sesay A, Modino S, Vanes L, Hernandez D, Linehan JM, Sharpe PT, Brandner S, Bliss TV, Henderson DJ, Nizetic D, Tybulewicz VL, Fisher EM (2005) An aneuploid mouse strain carrying human chromosome 21 with Down syndrome phenotypes. Science 309:2033-2037. CrossRef Medline 
Oppenheim RW, Flavell RA, Vinsant S, Prevette D, Kuan CY, Rakic P (2001) Programmed cell death of developing mammalian neurons after genetic deletion of caspases. J Neurosci 21:4752-4760. Medline

Ow YP, Green DR, Hao Z, Mak TW (2008) Cytochrome c: functions beyond respiration. Nat Rev Mol Cell Biol 9:532-542. CrossRef Medline

Pack SD, Weil RJ, Vortmeyer AO, Zeng W, Li J, Okamoto H, Furuta M, Pak E, Lubensky IA, Oldfield EH, Zhuang Z (2005) Individual adult human neurons display aneuploidy: detection by fluorescence in situ hybridization and single neuron PCR. Cell Cycle 4:1758-1760. CrossRef Medline

Pavelka N, Rancati G, Zhu J, Bradford WD, Saraf A, Florens L, Sanderson BW, Hattem GL, Li R (2010) Aneuploidy confers quantitative proteome changes and phenotypic variation in budding yeast. Nature 468:321-325. CrossRef Medline

Peterson SE, Westra JW, Rehen SK, Young H, Bushman DM, Paczkowski CM, Yung YC, Lynch CL, Tran HT, Nickey KS, Wang YC, Laurent LC, Loring JF, Carpenter MK, Chun J (2011) Normal human pluripotent stem cell lines exhibit pervasive mosaic aneuploidy. PLoS One 6:e23018. CrossRef Medline

Phillips JL, Hayward SW, Wang Y, Vasselli J, Pavlovich C, Padilla-Nash H, Pezullo JR, Ghadimi BM, Grossfeld GD, Rivera A, Linehan WM, Cunha GR, Ried T (2001) The consequences of chromosomal aneuploidy on gene expression profiles in a cell line model for prostate carcinogenesis. Cancer Res 61:8143-8149. Medline

Pompeiano M, Blaschke AJ, Flavell RA, Srinivasan A, Chun J (2000) Decreased apoptosis in proliferative and postmitotic regions of the caspase 3-deficient embryonic central nervous system. J Comp Neurol 423:1-12. CrossRef Medline

Rajagopalan H, Lengauer C (2004) Aneuploidy and cancer. Nature 432: 338-341. CrossRef Medline

Rajendran RS, Zupanc MM, Lösche A, Westra J, Chun J, Zupanc GK (2007) Numerical chromosome variation and mitotic segregation defects in the adult brain of teleost fish. Dev Neurobiol 67:1334-1347. CrossRef Medline

Rajendran RS, Wellbrock UM, Zupanc GK (2008) Apoptotic cell death, long-term persistence, and neuronal differentiation of aneuploid cells generated in the adult brain of teleost fish. Dev Neurobiol 68:1257-1268. CrossRef Medline

Rakic P (2005) Less is more: progenitor death and cortical size. Nat Neurosci 8:981-982. CrossRef Medline

Rehen SK, McConnell MJ, Kaushal D, Kingsbury MA, Yang AH, Chun J (2001) Chromosomal variation in neurons of the developing and adult mammalian nervous system. Proc Natl Acad Sci U S A 98:13361-13366. CrossRef Medline

Rehen SK, Yung YC, McCreight MP, Kaushal D, Yang AH, Almeida BS, Kingsbury MA, Cabral KM, McConnell MJ, Anliker B, Fontanoz M, Chun J (2005) Constitutional aneuploidy in the normal human brain. J Neurosci 25:2176-2180. CrossRef Medline

Rehen SK, Kingsbury MA, Almeida BS, Herr DR, Peterson S, Chun J (2006) A new method of embryonic culture for assessing global changes in brain organization. J Neurosci Methods 158:100-108. CrossRef Medline

Rubenstein JL, Rakic P (1999) Genetic control of cortical development. Cereb Cortex 9:521-523. CrossRef Medline

Schröck E, du Manoir S, Veldman T, Schoell B, Wienberg J, Ferguson-Smith MA, Ning Y, Ledbetter DH, Bar-Am I, Soenksen D, Garini Y, Ried T (1996) Multicolor spectral karyotyping of human chromosomes. Science 273:494-497. CrossRef Medline

Sheltzer JM, Amon A (2011) The aneuploidy paradox: costs and benefits of an incorrect karyotype. Trends Genet 27:446-453. CrossRef Medline

Slee EA, Zhu H, Chow SC, MacFarlane M, Nicholson DW, Cohen GM (1996) Benzyloxycarbonyl-Val-Ala-Asp (OMe) fluoromethylketone (ZVAD.FMK) inhibits apoptosis by blocking the processing of CPP32. Biochem J 315:21-24. Medline

Spits C, Mateizel I, Geens M, Mertzanidou A, Staessen C, Vandeskelde Y, Van der Elst J, Liebaers I, Sermon K (2008) Recurrent chromosomal abnormalities in human embryonic stem cells. Nat Biotechnol 26:1361-1363. CrossRef Medline

Staley K, Blaschke AJ, Chun J (1997) Apoptotic DNA fragmentation is detected by a semi-quantitative ligation-mediated PCR of blunt DNA ends. Cell Death Differ 4:66-75. CrossRef Medline

Sun XM, MacFarlane M, Zhuang J, Wolf BB, Green DR, Cohen GM (1999) Distinct caspase cascades are initiated in receptor-mediated and chemical-induced apoptosis. J Biol Chem 274:5053-5060. CrossRef Medline

Tai YT, Svendsen CN (2004) Stem cells as a potential treatment of neurological disorders. Curr Opin Pharmacol 4:98-104. CrossRef Medline

Thomaidou D, Mione MC, Cavanagh JF, Parnavelas JG (1997) Apoptosis and its relation to the cell cycle in the developing cerebral cortex. J Neurosci 17:1075-1085. Medline

Torres EM, Sokolsky T, Tucker CM, Chan LY, Boselli M, Dunham MJ, Amon A (2007) Effects of aneuploidy on cellular physiology and cell division in haploid yeast. Science 317:916-924. CrossRef Medline

Torres EM, Dephoure N, Panneerselvam A, Tucker CM, Whittaker CA, Gygi SP, Dunham MJ, Amon A (2010) Identification of aneuploidytolerating mutations. Cell 143:71-83. CrossRef Medline

Vakifahmetoglu H, Olsson M, Zhivotovsky B (2008a) Death through a tragedy: mitotic catastrophe. Cell Death Differ 15:1153-1162. CrossRef Medline

Vakifahmetoglu H, Olsson M, Tamm C, Heidari N, Orrenius S, Zhivotovsky B (2008b) DNA damage induces two distinct modes of cell death in ovarian carcinomas. Cell Death Differ 15:555-566. CrossRef Medline

Vitale I, Galluzzi L, Castedo M, Kroemer G (2011) Mitotic catastrophe: a mechanism for avoiding genomic instability. Nat Rev Mol Cell Biol 12: 385-392. CrossRef Medline

Weiner JA, Chun J (1997) Png-1, a nervous system-specific zinc finger gene, identifies regions containing postmitotic neurons during mammalian embryonic development. J Comp Neurol 381:130-142. CrossRef Medline

Westra JW, Peterson SE, Yung YC, Mutoh T, Barral S, Chun J (2008) Aneuploid mosaicism in the developing and adult cerebellar cortex. J Comp Neurol 507:1944-1951. CrossRef Medline

Westra JW, Rivera RR, Bushman DM, Yung YC, Peterson SE, Barral S, Chun J (2010) Neuronal DNA content variation (DCV) with regional and individual differences in the human brain. J Comp Neurol 518:3981-4000. CrossRef Medline

Wilkie AL, Jordan SA, Sharpe JA, Price DJ, Jackson IJ (2004) Widespread tangential dispersion and extensive cell death during early neurogenesis in the mouse neocortex. Dev Biol 267:109-118. CrossRef Medline

Williams BR, Prabhu VR, Hunter KE, Glazier CM, Whittaker CA, Housman DE, Amon A (2008) Aneuploidy affects proliferation and spontaneous immortalization in mammalian cells. Science 322:703-709. CrossRef Medline

Wiseman FK, Alford KA, Tybulewicz VL, Fisher EM (2009) Down syndrome-recent progress and future prospects. Hum Mol Genet 18:R75R83. CrossRef Medline

Yang AH, Kaushal D, Rehen SK, Kriedt K, Kingsbury MA, McConnell MJ, Chun J (2003) Chromosome segregation defects contribute to aneuploidy in normal neural progenitor cells. J Neurosci 23:10454-10462. Medline

Yoshida H, Kong YY, Yoshida R, Elia AJ, Hakem A, Hakem R, Penninger JM, Mak TW (1998) Apaf1 is required for mitochondrial pathways of apoptosis and brain development. Cell 94:739-750. CrossRef Medline

Yu W, Centonze VE, Ahmad FJ, Baas PW (1993) Microtubule nucleation and release from the neuronal centrosome. J Cell Biol 122:349-359. CrossRef Medline

Yung YC, Kennedy G, Chun J (2009) Identification of neural programmed cell death through the detection of DNA fragmentation in situ and by PCR. Curr Protoc Neurosci July Chapter 3:Unit 38.

Yurov YB, Iourov IY, Monakhov VV, Soloviev IV, Vostrikov VM, Vorsanova SG (2005) The variation of aneuploidy frequency in the developing and adult human brain revealed by an interphase FISH study. J Histochem Cytochem 53:385-390. CrossRef Medline

Yurov YB, Iourov IY, Vorsanova SG, Liehr T, Kolotii AD, Kutsev SI, Pellestor F, Beresheva AK, Demidova IA, Kravets VS, Monakhov VV, Soloviev IV (2007) Aneuploidy and confined chromosomal mosaicism in the developing human brain. PLoS One 2:e558. CrossRef Medline

Zheng TS, Flavell RA (1999) Apoptosis. All's well that ends dead. Nature 400:410-411. CrossRef Medline

Zhu H, Fearnhead HO, Cohen GM (1995) An ICE-like protease is a common mediator of apoptosis induced by diverse stimuli in human monocytic THP.1 cells. FEBS Lett 374:303-308. CrossRef Medline

Zupanc GK, Wellbrock UM, Sirbulescu RF, Rajendran RS (2009) Generation, long-term persistence, and neuronal differentiation of cells with nuclear aberrations in the adult zebrafish brain. Neuroscience 159:1338 1348. CrossRef Medline 